\title{
DEVELOPING COMMUNICATIVE-BASED INSTRUCTIONAL MODEL OF SPEAKING SKILL IN ELEMENTARY SCHOOL
}

\author{
Muammar'1, Suhardi $^{2}$, Ali Mustadi ${ }^{3}$ \\ Universitas Islam Negeri Mataram, Indonesia ${ }^{1}$, Universitas Negeri Yogyakarta, \\ Indonesia ${ }^{2,3}$ \\ E-mail: muammar@uinmataram.ac.id ${ }^{1}$, suhardi@uny.ac.id ${ }^{2}$, \\ ali_mustadi@uny.ac.id ${ }^{3}$
}

DOI: $10.14421 /$ al-bidayah.v12i2.588

\begin{abstract}
This study aims to develop a communicative-based instructional speaking skill model, in respect to experts' validation, practicality, and effectiveness in learning. The learning process was generated due to the unavailability of an instructional speaking skill model, which was predicted to help students verbalize their thoughts, ideas, and feelings. The method used was research and development (R\&D) technique, while the subjects included five experts/teachers and 26 students selected in the elementary school. Data collection were carried out through scale, observation, tests, and distribution of questionnaires, as well as analyzed descriptively and statistically, using a t-test method. The results showed that, the communicative-based instructional speaking skill model was practical, effective in improving students'verbal ability, and considered valid by the experts.
\end{abstract}

Keywords: instructional model; speaking skill; communicative

\section{INTRODUCTION}

According to the existing language ethics, speaking skills has been reported to increase students' ability to communicate effectively and efficiently, in Indonesia. ${ }^{1}$ The ability of students' speaking skills in elementary schools has been emphasized, since the beginning of enrolment. When this functional ability is well-mastered, the tendency to deliver ideas, thoughts, concepts, and feeling in other disciplines, also becomes possessed by the students ${ }^{2}$. Therefore, this skill is found to be an essential ability that should be developed in the global era, which is full of challenges and problems ${ }^{3}$.

In the 2013 Curriculum, speaking skills is known to continuously guide the development of students' verbal ability, without ignoring communicative competence.

${ }^{1}$ Kementerian Pendidikan dan Kebudayaan, Panduan Penguatan Proses Pembelajaran Sekolah Menengah Pertama, (Jakarta: Kemendikbud, 2013), 317.

${ }^{2}$ Yusutria, Yusutria, and Rina Febriana. "Aktualisasi Nilai-Nilai Kemandirian Dalam Membentuk Karakter Mandiri Siswa." Ta'dib: Jurnal Pendidikan Islam 8, no. 1 (May 1, 2019): 577-82. https://doi.org/10.29313/tjpi.v8i1.4575.

${ }^{3}$ Piirto, J. (2011). Creative for 21st Century Skill. Retrieved from http://ww.sensepublisher.com. 
Moreover, the primary purpose of these skills is to provide efficient communication ${ }^{4}$. However, it should be honestly acknowledged that the speaking skill of elementary school students does not meet the standard expectations ${ }^{5}$. This condition is observed to be closely related to speaking in elementary school, which is supposed to be failed in helping students think and use language skillfully ${ }^{6}$. Based on teaching experiences, speaking skills tend to be underestimated, due to the consideration of the mother tongue used in students' daily communication ${ }^{7}$. Due to this result, the speaking ability of elementary school students is known to be at a low level. The indicators used by teachers to measure the students' speaking ability are the accuracy of stress, pronunciation, vocabulary/diction/word choice, sentence structure, fluency, material mastery, attitude, and encouragement ${ }^{8}$. Furthermore, speaking is a fundamental and primary skill after listening, during the learning process (42\% listening, 32\% speaking, 15\% reading, and $11 \%$ writing $)^{9}$. Ideally, students should been trained to speak very often, listen to evaluation from other people, compete in a contest, be vocal in other groups, and record all that has been discussed ${ }^{10}$.

One of the approaches believed to have created situations and conditions for active speaking skills in elementary school, is the communicative method. This approach is based on the view that the ability to effectively use language in communication, is the goal that should be achieved in learning processes ${ }^{11}$. Through the communicative approach, students are challenged to understand and use language naturally, during the

${ }^{4}$ Atmazaki Atmazaki, "Implementasi Kurikulum 2013 Mata Pelajaran Bahasa Indonesia: Pola Pikir, Pendekatan Ilmiah, Teks (Genre), Dan Penilaian Otentik," International Conference on Languages and Arts 0, no. 0 (October 31, 2013): 15-22, http://ejournal.unp.ac.id/index.php/isla/article/view/3962.

5 Yunus Abidin, Pembelajaran Bahasa Berbasis Pendidikan Karakter. Cet. Ke-3, (Bandung: PT Refika Aditama, 2015), 133.

${ }^{6}$ Rahayu Surtiati Hidayat, "Humaniora Dalam Pengembangan Pendidikan Tinggi: Linguistik Terapan Sebagai Bidang Pendidikan Dan Penelitian” (PhD Thesis, Fakultas Ilmu Pengetahuan Budaya, Universitas Indonesia, 2006).

7 Muqarramah Sulaiman Kurdi et al., "Speaking Activities In Madrasah Ibtidaiyah: A Meta Narrative About Character Building And Multiculturalism Point Of View," Al-Bidayah : Jurnal Pendidikan Dasar Islam 12, no. 1 (June 30, 2020): 55-82, https://doi.org/10.14421/al-bidayah.v12i1.534.

${ }^{8}$ Iskandarwassid \& Dadang Sunendar, Strategi Pembelajaran Bahasa, (Bandung: Rosda, 2008).

9 Ahmad Rofi'Uddin and Darmiyati Zuhdi, Pendidikan Bahasa Dan Sastra Indonesia Di Kelas Tinggi (Proyek Pendidikan Guru Sekolah Dasar (Primary School Teacher Development ..., 1998).

${ }^{10}$ Marriam Bashir, Muhammad Azeem, and Ashiq Hussain Dogar, "Factor Effecting Students' English Speaking Skills," British Journal of Arts and Social Sciences 2, no. 1 (2011), http://widyawatipalupi.blogs.uny.ac.id/wp-content/uploads/sites/15732/2018/04/Factors-effectingstudents-speaking-skill.pdf.

11 Jack C. Richards, Communicative Language Teaching Today (SEAMEO Regional Language Centre Singapore, 2005). 
process of communication with other persons and social context. Therefore, language learning should be stressed on the practical use of the speaking skills as an equipment of communication, not knowledge ${ }^{12}$.

This idea is observed to be in line with Mustadi's view, which stated that language teachers and curriculum researchers believed the communicative model was more effective in various teaching and learning programs, by increasing active communicational ability than the traditional approach, which was grammar-oriented ${ }^{13}$. Besides that, the students became more passive in the conventional approach, due to the fact that it is dominated by language knowledge than skill tasks ${ }^{14}$. However, the communicative approach in this study is limited to speaking skills ${ }^{15}$.

The teaching of speaking skill is hoped to direct the ability of students into effectively, genuinely, honestly, correctly, and responsibly using Indonesian language for communicational purposes in various situations, such as greetings, expressing opinions \& feelings, asking questions, identification processes, providing answers, and more, without having to deal with psychological problems, which includes feeling embarrassed, inferiority, nervousness, and other verbal difficulties ${ }^{16}$. This means that speaking ability should be taught, in order to develop cognitive and affective skills, such as being respectful, by upholding values of tolerance, sympathy, and empathy. This also means that good behaviour practice in the verbal learning process is very essential, to the extent that students become more active in speaking, and are accustomed to using polite languages, which are strongly influenced by social contexts ${ }^{17}$. Therefore, in order to

12 Ratna, Ellya, "Pengembangan Materi Ajar Bahasa Indonesia Berdasarkan Pendekatan Komunikatif”, Jurnal Bahasa dan Seni. Padang: FBSS UNP Press. 7, 2, 1411 -3732 (2006).

${ }^{13}$ Ali Mustadi, Communication Competence Based Language Teaching: An English Course Design For Primary Teacher Education (Yogyakarta: UNY Press, 2013).

${ }^{14}$ Dissaya Supharatypthin, “Developing Students' Ability In Listening And Speaking English Using The Communicative Approach Of Teaching," International Journal of Arts \& Sciences 7, no. 3 (2014): 141-49, https://search.proquest.com/openview/826a03fb9d977240569d829d126fe56f/1?pqorigsite $=$ gscholar \&cbl $=626342$.

${ }^{15}$ Moon Woo Lee, "Will Communicative Language Teaching Work? Teachers' Perceptions Toward The New Educational Reform In South Korea," Indonesian Journal of Applied Linguistics 3, no. 2 (January 2, 2014): 1-17, https://doi.org/10.17509/ijal.v3i2.265.

${ }^{16}$ Burhan Nurgiyantoro, "Penilaian Pembelajaran Sastra Berbasis Kompetensi," Yogyakarta: BPFe, 2010, 399.

${ }^{17}$ Sukarno Sukarno, "Politeness Strategies, Linguistic Markers And Social Contexts In Delivering Requests In Javanese," Indonesian Journal of Applied Linguistics 7, no. 3 (January 31, 2018): 659-67, https://doi.org/10.17509/ijal.v7i3.9816. 
increase students' functional verbal ability in elementary schools, it is essentially necessary to develop a communicative-based instructional speaking skill model.

In this study, the communicative-based instructional speaking skill model is a plan that is to be used as a reference, in order to create any language programs, including speaking classes, where teaching and learning processes are arranged and implemented, based on communicative instructions and components, such as the syntax, social and supporting system, reaction principle, as well as instructional and accompanying impact $^{18}$.

\section{RESEARCH METHODS}

This study employed the use of educational research and development (R\&D), which was designed by Borg \& Gall as a grand idea ${ }^{19}$. Also, the focus of this research was more on the development and validation of the method being developed, which was a communicative-based instructional speaking skill model. Besides proof, this study also tried to observe the practicability and effectiveness of implementing the model, in order to enhance students' active speaking abilities, as well as use instruments with tested validity and reliability.

The subjects in this study were experts/practitioners (professor and doctoral teachers) and the fifth-grade students of elementary schools. Also, the research location was Public Elementary School 26, Cakranegara, which was selected due to its application of the 2013 Curriculum.

The objects of this study were,

(1) The experts/practitioners' responses,

(2) The observer's responses,

(3) The students' and teachers' responses,

(4) The students' active speaking skills.

Furthermore, two aspects of students' active speaking ability dimension was referred to, namely lingual and non-lingual. Regarding the lingual aspect, the observed elements were stress, pronunciation, vocabulary/diction, and language structure.

\footnotetext{
${ }^{18}$ Richard Arends, Classroom Instructional Management, (New York: The Mc Graw-Hill Company, 1997), 7

${ }^{19}$ Meredith Damien Gall, Walter R. Borg, and Joyce P. Gall, Educational Research: An Introduction (Longman Publishing, 1996).
} 
However, the elements observed in the non-lingual aspect were fluency, material mastery, attitude, and encouragement.

Moreover, the data on the experts/practitioners' responses were obtained through scale, the practicability of the model implementation, and the teacher's ability to manage instruction via the developed technique. The data on the students' and teachers' activities were also collected using an observation sheet, with the information of their responses being elicited through a questionnaire. The data on the students' active speaking ability were also collected, through the use of a verbal ability performance test. The analysis of the data was also carried out, using descriptive technique and t-test statistics. ${ }^{20}$ As the descriptive technique was being used to present a general description of the research results, the t-test statistics analyzed the difference in average score, between the students' final and initial speaking abilities. This statistical test was carried out at a 5\% significance level.

\section{RESULT AND DISCUSSION}

\section{Communicative Competence}

As means of communication in real-life situations, the belief in language roles led to a question,

"what does a person need to do, in order to possess the ability of speaking with maximum results (to reach perfect communication purpose)?"

The answer provided to this question was that, an individual needs to have communicational language ability, which is also known as communicative competence.

In communicational language teaching, communicative competence was observed to be the fundamental construct. This means that when the curriculum is to be designed, the elements, which are to develop communicative competence, should be understood. It should also be noted that, this crucial construct was created in 1980. During its creation, some experts were reported to have designed the construct of communicative competence, which became more comprehensive with the understanding of language nature, as an equipment of communication in real-life situations. It was also reported that an element had existed from the beginning, with other additions being made later on, through different models. However, this current model showed a more comprehensive

20 Burhan Nurgiyantoro, Statistik Terapan Untuk Penelitian Ilmu-Ilmu Sosial (Gadjah Mada University Press, 2004). 
development, compared to previous designs. The story of the model is shown in Figure 1 .

$$
\text { Canale \& Swain } 1980 \quad \text { Canale } 1983 \quad \text { Celce-Murcia, Dornyei, Thurrell } 1995
$$

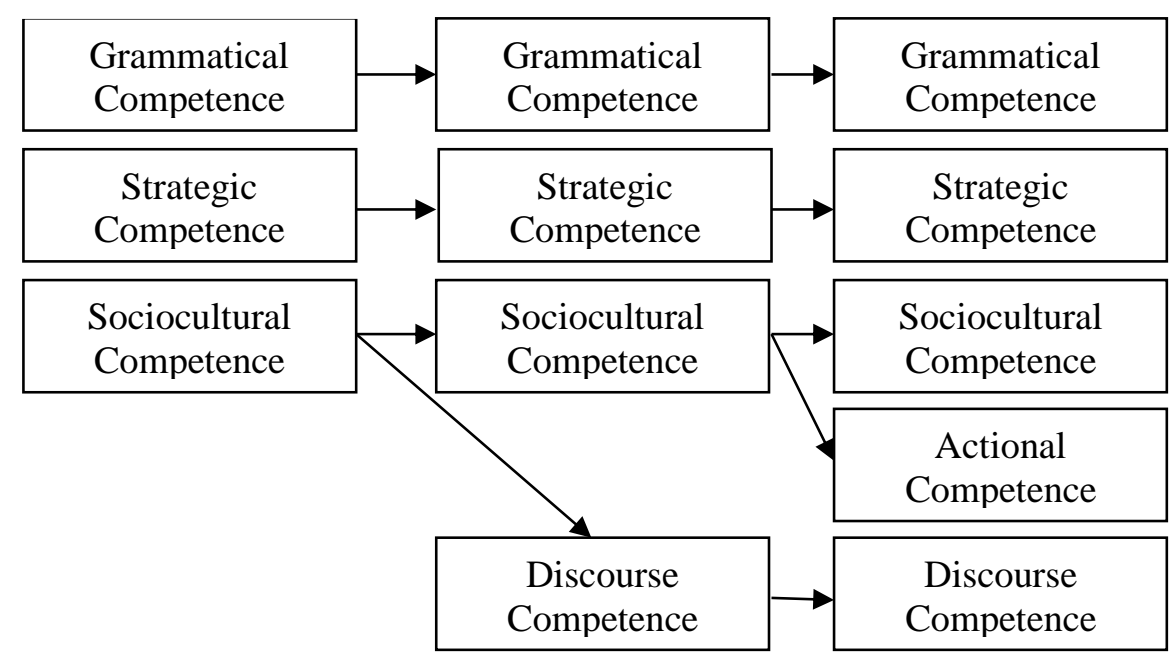

Figure 1

Chronological Evolution of Communicative Competence Model $^{21}$

Moreover, all models of language teaching and learning often referred to the communicative competence model above. It was also observed that all the models admitted the importance of Grammatical (knowledge about grammar rules, vocabulary, pronunciation, spelling, and more), Strategical (knowledge about verbal and non-verbal communicational strategy, which increases efficiency and overcome deadlock), Sociocultural (awareness about cultural understanding and inter-cultural assumption), Actional (the ability to use language correctly, precisely, and fluently, in order to reach communicational purpose), and Discourse (the ability to combine language structure into various cohesive texts) Competences.

\section{Communicative Competence Model in Increasing Students' Active Speaking Skill}

The enhancement to maximum active speaking skills is likely to be achieved, when students are reported to have mastered communicative competence. This competence is very much needed by the students, in order for them to achieve a perfect communication purpose.

${ }^{21}$ Marianne Celce-Murcia and And Others, "Communicative Competence: A Pedagogically Motivated Model with Content Specifications," Issues in Applied Linguistics 6, no. 2 (1995): 5-35, https://eric.ed.gov/?id=EJ542906. 
As explained above, students need to master five kinds of communicative competence in speaking, namely grammatical, strategical, sociocultural, actional, and discourse competences ${ }^{22}$. These competencies are interrelated and inseparable when speaking.

In improving the students' active speaking ability, the communicative element that was to be mastered was actional competence, which dealt with the ability to use language correctly (according to grammatical rules), precisely (according to the situation - with those they speak with, and the formality level of a problem), and fluently (not stuttering), in order to attain communicational purpose. Hiwever, other elements, such as grammatical, strategical, sociocultural, and discourse competencies were unable to be ignored.

From the explanation, it was stated that by referring to communicative competence, teachers provided appropriate attention to the teaching and learning of language form and meaning, as a unit of communication equipment. Additionally, there were no doubts about the importance of helping students to learn grammar, vocabulary, pronunciation, spelling, and punctuation, as all were aimed at supporting their abilities to use the target language to speak. Therefore, actional competence became the basis for increasing the students' active speaking ability. In order to make this more comprehensive, visualization was provided in Figure 2 below.

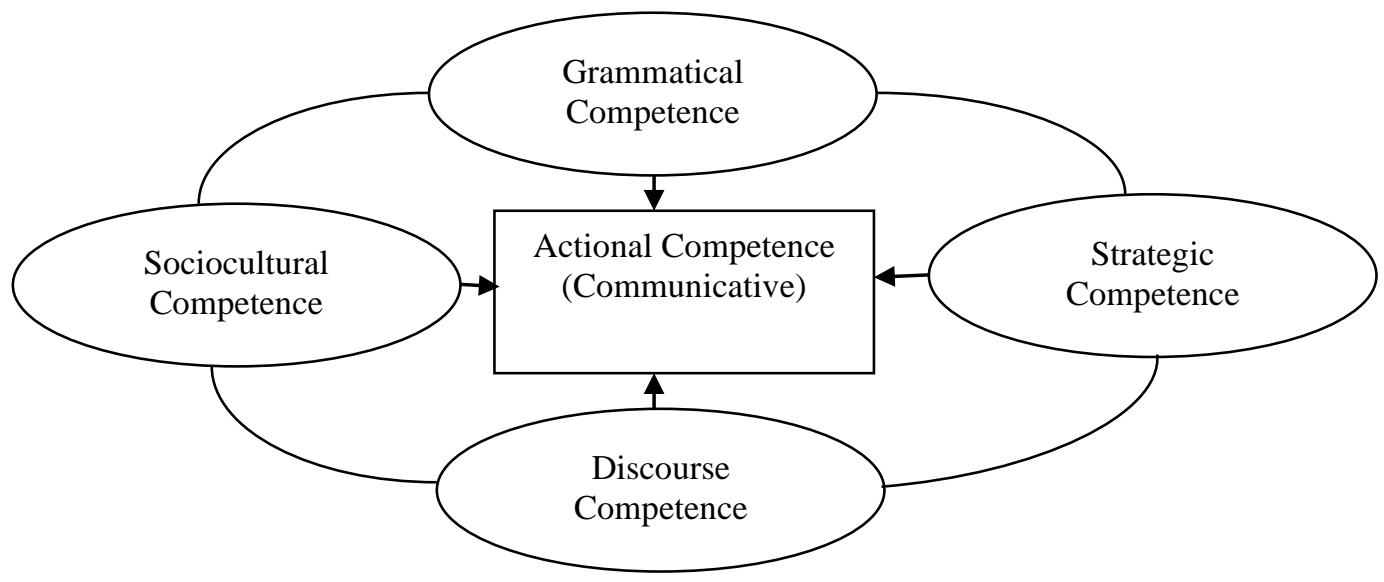

Figure 2

Communicative Competence Model in Increasing the Students' Active Speaking Skill

${ }^{22}$ Kentarsih Rabawati, M. Sutama, and M. Gosong, "Penerapan Pendekatan Komunikatif Dalam Pembelajaran Bahasa Indonesia Siswa Kelas XI Smk Negeri 1 Denpasar," Jurnal Pendidikan Dan Pembelajaran Bahasa Indonesia 2, no. 0 (May 22, 2013), https://ejournalpasca.undiksha.ac.id/index.php/jurnal_bahasa/article/view/581. 
Based on Figure 2, it was stated that actional competence aimed to be obtained by the students. This meant that the students' active speaking abilities, in order to use language correctly, precisely, and fluently, were expected to be achieved. Also, this achievement was observed to be inseparable from other communicative competences (grammatical, strategical, sociocultural, and discourse). Therefore, the students' active speaking skill improvement should be in a significant relationship with the mastery of the five communicative competences, which involves focusing on one element, as well as not ignoring others.

\section{The Validity of Research Instrument}

Generally, the instruments developed in this study attained the criteria set for proper tools, even though there were still some revisions. It was observed that these devices were revised, based on the inputs provided by the experts. Therefore, the instruments were qualified to be applied in evaluating the model and instructional equipment developed. The result of experts'/practitioners' evaluation was also observed to be related to the tool developed, which is shown in Table 1 below.

\section{Table 1}

Evaluation of Research Instrument Validity

\begin{tabular}{|c|c|c|c|c|c|c|c|}
\hline \multirow[b]{2}{*}{ No } & \multirow[b]{2}{*}{ Instrument Name } & \multicolumn{3}{|c|}{$\begin{array}{l}\text { Evaluation Result by } \\
\text { Evaluator Team }\end{array}$} & \multicolumn{2}{|c|}{ Frequency } & \multirow{2}{*}{ 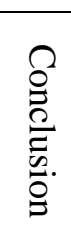 } \\
\hline & & V1 & $\mathrm{V} 2$ & V3 & $\begin{array}{l}\mathrm{LD} / \\
\mathrm{LDR}\end{array}$ & TLD & \\
\hline 1. & Construct Validation & LD & LD & LD & 3 & 0 & LD \\
\hline 2. & Content Validation & LD & LDR & $\mathrm{LD}$ & 3 & 0 & LD \\
\hline 3. & Teacher's Book Validation & LDR & LD & LD & 3 & 0 & LD \\
\hline 4. & Student's Book Validation & LD & LD & LDR & 3 & 0 & LD \\
\hline 5. & Lesson Plan Validation & LD & LD & LD & 3 & 0 & LD \\
\hline 6. & $\begin{array}{l}\text { Performance Test of Speaking Skill } \\
\text { Validation }\end{array}$ & LD & LD & LD & 3 & 0 & LD \\
\hline 7. & $\begin{array}{l}\text { Observation Sheet of Learning } \\
\text { Model's Implementation }\end{array}$ & LDR & LD & LD & 3 & 0 & LD \\
\hline 8. & $\begin{array}{l}\text { Observation Sheet of Teacher's } \\
\text { Ability to Manage Learning }\end{array}$ & LD & LD & LDR & 3 & 0 & LD \\
\hline 9. & $\begin{array}{l}\text { Observation Sheet of Teacher and } \\
\text { Students' Activity }\end{array}$ & LD & LDR & LD & 3 & 0 & LD \\
\hline 10. & $\begin{array}{l}\text { Questionnaire of Students and } \\
\text { Teacher's Response }\end{array}$ & LDR & LD & LD & 3 & 0 & LD \\
\hline & Total & & & & 30 & $\mathbf{0}$ & LD \\
\hline
\end{tabular}

Explanation: LD (Proper to Use) and LDR (Proper to Use with Revision) 
Table 1 was the general evaluation result recapitulation by each evaluator, which was concerned with the necessary instruments to collect data on validity, practicability, and effectiveness of the instructional model developed. Instead of determining assessment criteria, the evaluator also provided inputs as consideration for revising the instruments.

The instrument assessment sheet being filled by the evaluator, consisted of the "YES" and "NO" answer options. Afterwards, general evaluation was conducted by the evaluator, in order to know whether the instrument was proper, suitable [with revision], or improper to use (LD, LDR, \& TLD). When the frequency of LD \& LDR was higher than TLD, the instrument was deemed fit to use after being revised, based on the descriptive input from the evaluator. Therefore, the evaluation provided showed that the tools were proper to be used, after making revisions on some indicators.

\section{The Validity of Communicative-Based Instructional Model of Speaking Skill and Its Instructional Equipments}

Experts or practitioners were observed to have validated the draft of the developed communicative-based instructional speaking skill model. This draft was validated by using the construct and content validation instrument, obtained from the excellent book to be used. The results of the developed book model was shown in Table 2, as follow,

Table 2

Validation of Communicative-Based Instructional Book Model of Speaking Skill

\begin{tabular}{ccccccccc}
\hline \multirow{2}{*}{ No. } & Validation & \multicolumn{4}{c}{ Evaluator's general evaluation } & Average & Category \\
& Aspect & V1 & V2 & V3 & V4 & V5 & score & \\
\hline 1. & Construct & 87 & 95 & 96 & 95 & 97 & 94 & Valid \\
2. & Content & 127 & 119 & 137 & 133 & 133 & 130 & Valid
\end{tabular}

Based on Table 2, it was observed that the average score of the construct and content validation of the communicative-based instructional speaking skill book model, fulfilled the validity criteria for the teaching of Indonesian subject, in the fifth-grade of Elementary School. Moreover, the use of the instructional model was carried out, in order to obtain input during the field testing. The whole data on the instructional equipment validation, which had been evaluated by the experts/practitioners, were displayed in Table 3 , as follow, 
Table 3

The Data on Validation of the Instructional Equipment

\begin{tabular}{llccccccc}
\hline \multirow{2}{*}{ No. } & \multirow{2}{*}{ Learning Equipment } & \multicolumn{8}{c}{ Validator's Average Score } & Average & \multirow{2}{*}{} \\
& & V1 & V2 & V3 & V4 & V5 & Score & Category \\
\hline 1. & Teacher's Book & 44 & 46 & 44 & 46 & 46 & 45 & Valid \\
2. & Student's Book & 101 & 100 & 104 & 104 & 105 & 103 & Valid \\
3. & Lesson Plan & 45 & 46 & 48 & 48 & 48 & 47 & Valid \\
& Performance Test of & 27 & 26 & 28 & 27 & 27 & 27 & Valid \\
4. & Speaking Skill & & & & & & & \\
\hline
\end{tabular}

Furthermore, it was observed that Table 3 was the validity criteria achievement of the instructional equipment developed, as the whole kit was considered valid and appropriate, by the evaluation team. Additionally, the equipment should be used to conduct field test on the developed communicative-based instructional speaking skill model.

The trial of the developed product, which had been improved based on the inputs from experts or practitioners, was then conducted, in order to obtain the data on the instructional model implementation (practicability and effectiveness). Moreover, this trial was conducted through teaching and learning processes in the classroom, by a colleague teacher. In order to obtain the data needed, two observers were engaged to monitor the teaching and learning processes in the school, via the use of the developed instructional model.

\section{The Practicability of the Implementation of Communicative-Based Instructional Model of Speaking Skill}

The communicative-based instructional speaking skill model was considered practical, when it was suitable for the evaluation criteria, which was set for practicability via observation sheets, and filled in by observers. This practicability was reported to be obtained, through the observation of teaching and learning activities in the classroom. Moreover, Table 4 was observed to present the average score obtained, in each component of the instructional model implementation. 
Table 4

The Data on Observation of The Implementation of the Instructional Model

\begin{tabular}{|c|c|c|c|c|c|c|c|c|c|}
\hline \multirow{3}{*}{ No. } & \multirow{3}{*}{$\begin{array}{l}\text { Observed } \\
\text { Aspects }\end{array}$} & \multicolumn{8}{|c|}{ Observer's Evaluation Score } \\
\hline & & \multicolumn{2}{|c|}{ I } & \multicolumn{2}{|c|}{ II } & \multicolumn{2}{|c|}{ III } & \multicolumn{2}{|c|}{ IV } \\
\hline & & 1 & 2 & 1 & 2 & 1 & 2 & 1 & 2 \\
\hline 1. & Syntax & 21 & 21 & 21 & 24 & 27 & 27 & 30 & 29 \\
\hline 2. & Social System & 19 & 20 & 22 & 23 & 24 & 27 & 26 & 29 \\
\hline \multirow[t]{5}{*}{3.} & Reaction & 8 & 9 & 11 & 12 & 13 & 13 & 14 & 15 \\
\hline & Principal & & & & & & & & \\
\hline & Total & 48 & 50 & 54 & 59 & 64 & 67 & 70 & 73 \\
\hline & Average Score & \multicolumn{8}{|c|}{61} \\
\hline & Category & \multicolumn{8}{|c|}{ High } \\
\hline
\end{tabular}

Based on the results of Table 4, it was observed that the practicability of the instructional model achieved an average score of 61 . This meant that the practicability of the instructional model was categorized into high or operationally, as criteria to be used in the field was fulfilled.

\section{The Effectiveness of Communicative-Based Instructional Model of Speaking Skill}

The results of the communicative-based instructional speaking skill model implementation, was reported to have been obtained through verbal ability pretests and posttests. In these cases, the students' speaking abilities were used to measure the effectiveness of the instructional model. The data analysis on this trial was intended to describe the average score (M) and standard deviation (SD), as well as test the mean similarity of the speaking ability, before and after implementation of the communicativebased instructional speaking skill model. Moreover, the test of average score similarity also used the t-test with a 5\% significance level. Therefore, the description of the average score and standard deviation of the students' speaking abilities before and after implementing the instructional model, was presented in Table 5.

Table 5

Average Score (M) and Standard Deviation (SD) of the Students' Active Speaking Ability

\begin{tabular}{cccccc}
\hline & After & & \multicolumn{3}{c}{ Before } \\
\hline $\mathrm{M}$ & SD & Qualification & $\mathrm{M}$ & SD & Qualification \\
78.77 & 8.62 & Good & 66.22 & 8.32 & Poor \\
\hline
\end{tabular}


Based on the results of Table 5, it was qualitatively indicated that the average score of the students' speaking abilities, before the implementation of the communicativebased instructional speaking skill model, tended to be deficient in a category. However, after implementation, the average score of the students' speaking abilities became good.

In order to discover the significance of improvement, testing of difference was carried out, via a t-test method. As an assumption, the data of the t-test before and after the implementation of the instructional model, was expected. Afterwards, it was observed that the variance between the results of the pretest and posttest of the students' speaking abilities, was homogenous.

In order to also test the normality of the data distribution, the statistical models of Kolmogorov-Smirnov and Shapiro-Wilk were used. Generally, the data on speaking ability were observed to be distributed, when one or both of the statistical values had a significant score higher than 0.05 . The result of the analysis is presented in Table 6 .

Table 6

Average Score (M) and Standard Deviation (SD) of Speaking Ability

\begin{tabular}{cccccccc}
\hline \multirow{2}{*}{ Source } & & \multicolumn{3}{c}{ Kolmogorov-Smirnov } & \multicolumn{3}{c}{ Shapiro-Wilk } \\
& & Statistic & df & Sig. & Statistic & df & Sig. \\
\hline \multirow{2}{*}{ Speaking Ability } & Initial & 0.145 & 35 & 0.59 & 0.944 & 35 & 0.075 \\
& Final & 0.095 & 35 & 0.200 & 0.955 & 35 & 0.161 \\
\hline
\end{tabular}

The result of Table 6, indicated that the statistical values of Kolmogorov-Smirnov and Shapiro-Wilk for both pretest and posttest score distributions, mostly had significant values higher than 0,05 . Therefore, the pretest and posttest scores were normally distributed.

To also test for the homogeneity of variance between the pretest and posttest scores of the students' speaking abilities, Levene statistics were used. The testing criteria applied stated that variance was considered homogenous, when the significant values of the Levene average score derived from sources (mean, Median, Median with adjusted $d f$, and trimmed mean), were higher than 0,05 . The results of this homogeneity test is presented in Table 7. 
Table 7

The Result of the Homogeneity of Variance between Pretest and Posttest Score of the Students' Speaking Ability

\begin{tabular}{|c|c|c|c|c|c|}
\hline \multicolumn{2}{|c|}{ Source } & Levene & df1 & df2 & Sig. \\
\hline & & Statistic & & & \\
\hline \multirow{5}{*}{$\begin{array}{c}\text { Speaking } \\
\text { Ability }\end{array}$} & Based on Mean & 0.001 & 1 & 68 & 0.980 \\
\hline & Based on Median & 0.002 & 1 & 68 & 0.963 \\
\hline & Based on Median and with & 0.002 & 1 & 67.18 & 0.963 \\
\hline & Adjusted df & & & & \\
\hline & Based on Trimmed Mean & 0.002 & 1 & 68 & 0.962 \\
\hline
\end{tabular}

Table 7 indicated that most variance of the whole sources had significant scores, which were higher than 0.05 . Therefore, the variance between the pretest and posttest scores of the speaking abilities, were homogenous.

The next test to be conducted was for the differences between pretest and posttest scores of the speaking abilities, where a t-test method was used. The results of this test was presented in Table 8 .

Tabel 8

The Result of Differences Testing of Pair Pretest and Postest Average Score of the Students'Speaking Ability

\begin{tabular}{|c|c|c|c|c|c|c|c|c|c|}
\hline \multirow{6}{*}{\multicolumn{2}{|c|}{ Pair Mean }} & \multirow{6}{*}{ M } & \multicolumn{4}{|c|}{ Paired Differences } & \multirow[t]{6}{*}{$\mathrm{t}$} & \multirow[t]{6}{*}{$\mathrm{df}$} & \multirow{6}{*}{$\begin{array}{l}\text { Sig. } \\
(2- \\
\text { tailed) }\end{array}$} \\
\hline & & & \multirow{5}{*}{$\begin{array}{c}\text { Std. } \\
\text { Deviation }\end{array}$} & \multirow{5}{*}{$\begin{array}{c}\text { Std. } \\
\text { Error } \\
\text { Mean }\end{array}$} & \multicolumn{2}{|c|}{$95 \%$} & & & \\
\hline & & & & & \multicolumn{2}{|c|}{ Confidence } & & & \\
\hline & & & & & \multicolumn{2}{|c|}{ Interval } & & & \\
\hline & & & & & \multicolumn{2}{|c|}{ Difference } & & & \\
\hline & & & & & Lower & Upper & & & \\
\hline \multirow[t]{2}{*}{ Model } & Final- & 12.54 & 1.70 & 0.28 & 13.12 & 11.95 & 43.55 & 34 & 0.000 \\
\hline & Initial & & & & & & & & \\
\hline
\end{tabular}

According to Table 8, it was stated that the statistical values showed a significant t-score, which was lower than 0.05. Therefore, the null hypothesis, which stated that, "There is no difference between the posttest and pretest score of the students' speaking ability," was rejected. However, the alternative hypothesis, which stated that, "There is a 
difference between the posttest and pretest score of the students' speaking ability," was accepted. When the distribution of the average score and standard deviation in Table 5 was observed, the posttest value of students' speaking ability was found to be higher than the initial. This indicated that the communicative-based instructional speaking skill model increased the students' verbal ability. Therefore, this instructional model was accepted to be relevant in improving the students' speaking abilities.

Based on the aforementioned explanation, experts'/practitioners' validation showed that the developed instructional model and its components were categorized as valid. This was due to the fact that the setting of the communicative-based instructional speaking skill model applied a systematic research and development method by Borg \& Gall, in this study. Moreover, from the result of the instructional model's practicability, it was observed that the average score was high, indicating that the speaking skill method was easy to use. Finally, the result of the instructional model's effectiveness showed that the posttest score of the students' speaking ability was higher, compared to that of the pretest.

Furthermore, the experts/practitioners provided positive responses towards the communicative-based instructional speaking skill model, based on the study results. This meant that the model was valid and suitable to be used in the teaching and learning of Indonesian, in elementary schools.

The communicative-based instructional speaking skill model, which resulted from development activity in this research, had some strengths. Firstly, the model was developed based on relevant rationale, sufficient theoretical basis, and working procedure (teaching and learning). The procedure comprehensively presented the teaching and learning steps, social and supporting systems, reaction principle, as well as educational impacts with its accompanying implications. Also, this model was observed to be practically and effectively implemented in elementary schools. Secondly, the model was developed based on the learning needs, therefore, it helped the teachers in creating innovative instructions and efficient facilities, in order to solve the students' problems. Thirdly, it was developed via the use of a scientific procedure, which strengthened the model's validity. Fourthly, the instructional model was interestingly and easily implemented by the teacher. Generally, the communicative-based instructional speaking 
skill model was principally suitable for implementation, both in a limited and broader scope.

Based on the instructional model implementation in limited scope, the practicability was categorized as high, or had operationally fulfilled the criteria set for it to be used in the field. Some of the reasons for these was that,

(1) The model had easy procedures or syntax to be applied,

(2) The model had a social system that was easy to be implemented,

(3) The model had a democratic and humanistic reaction principle,

(4) The model had an excellent supporting system, leading to its development from daily life language environment.

The practicability results became proof that the implementation of this communicativebased instructional model was proper to be used, in order to develop a communication purpose.

The result of this research was matched with the study of Rabawati et al., which stated that the teacher applied a communicative approach appropriately in the teaching of Indonesian, as well as emphasizing the students' activities. Based on being a facilitator, the teacher only explained the lessons when it was necessary. However, the obstacles encountered by the teacher were,

(1) The students seemed shy in expressing their opinions,

(2) The Indonesian used did not conform with the existing rules,

(3) It was hard to obtain appropriate and exciting materials for each student,

(4) More time to implement the model in the classroom was demanded.

A communicative approach was defined as the method that enabled teachers to use numerous techniques, in order to encourage students in developing communicational competence. ${ }^{23}$

Furthermore, Rugare Mareva \& Shumirai Nyotain's research recommended that English teachers should apply communicative language teaching entirely, due to the fact

${ }^{23}$ Kentarsih Rabawati, M. Sutama, and M. Gosong, "Penerapan Pendekatan Komunikatif Dalam Pembelajaran Bahasa Indonesia Siswa Kelas XI Smk Negeri 1 Denpasar," Jurnal Pendidikan Dan Pembelajaran Bahasa Indonesia 2, no. 0 (May 22, 2013), https://ejournalpasca.undiksha.ac.id/index.php/jurnal_bahasa/article/view/581. 
that it was practical and effective ${ }^{24}$. However, in the research of Asna Yuliati, it was asserted that when viewed from a competence aspect, the fifth-grade students of Karangkembang Public Elementary School achieved good grades, through the use of communicative approach in the teaching and learning process of Indonesian. ${ }^{25}$

The aforementioned explanation confirmed that the communicative approach was very relevant to be used as the basis for teaching and learning of speaking skills, both theoretically and empirically. This approach in the teaching and learning of speaking skills was observed to be beneficial for teachers, in order to promote meaningful education.

The implementation of communicative-based instructional speaking skill model also provided practical teaching and learning impact in a limited scope. The proof was observed from the test result in the study, where the average score of the students' speaking ability was significantly higher than that of the initial observation. The effectiveness of this instructional model, especially in promoting active speaking ability, confirmed that the communicative approach definitely increased the students' functional verbal skills.

Moreover, the result of this research was also similar to that of Anggun Kirana Putri, which stated that there was a significant influence between the use of instructional approach and the level of students' motivation in increasing the English speaking skill. This level of motivation involved the difference in the increase of the students' speaking skill, which was between those with high and low reasons, as well as the use of communicative and expository approaches ${ }^{26}$. Also, the study of Feti Ramadani, explained that communicative approach had successfully increased the speaking ability of the fourth-grade students in Teladan Public Elementary School, during teaching and learning processes of English Language ${ }^{27}$.

${ }^{24}$ Rugare Mareva \&Shumirai Nyota, "Structural or Communicative Approach: a Case Study of English Language Teaching in Masvingo Urban and Peri-Urban Secondary Schools”, Internal Journal of English and Literature Vol. 3(5), pp. 103-111 (2012).

25 Asna Yuliati, "Penerapan Pendekatan Komunikatif dalam Pembelajaran Bahasa Indonesia", Jurnal Wahana Pedagogika. Lamongan: Universitas Islam Darul Ulum, Vol. 2, No. 1, Juni 2016.

${ }^{26}$ Anggun Kirana Putri, Kartika Chrysti S. \& Suripto, "Pendekatan Komunikatif dalam Peningkatan Keterampilan Berbicara Bahasa Inggris Dilihat dari Motivasi Belajar Siswa”, Jurnal FKIP-UNS, 2012.

${ }^{27}$ Feti Ramadani, "Pengaruh Penerapan Pendekatan Komunikatif Terhadap Keterampilan Berbicara Siswa Kelas IV Pada Pembelajaran Bahasa Inggris Di Madrasah Ibtidaiyah Negeri 1 Teladan Palembang” (PhD Thesis, UIN RADEN FATAH PALEMBANG, 2017). 
In the study of Suwarsih Madya, it was also explained that in many language programs, teachers and curriculum researchers had admitted that communicative approach was a more effective way of learning, in order to increase the students' active communication ability, compared to the traditional method, which only focused on grammar. With the conventional approach, the students became more passive, due to being more dominated by language knowledge than skills. ${ }^{28}$

Also, the research of Supharatypthin insisted that, the communicative approach was believed to be one of the most effective methods in helping the students increase their listening and speaking skills ${ }^{29}$. This approach was also supposed to be one of the most effective in language teaching and learning, according to The National Curriculum Board and Textbook, as well as linguistic teachers. ${ }^{30}$

The prepositional and theoretical implication that was formulated from this research were,

(1) The communicative-based instructional speaking skill model was implemented via the use of text-based language teaching and learning, which had continually provided reinforcement in improving the students' active verbal ability. The implication is that the students' functional speaking abilities are obtained, when the texts and materials provided are based on real-life,

(2) The communicative-based instructional speaking skill model was a tool for teachers to increase students' functional verbal ability, through the continuous provision of practices, both in groups or individually. The implication is that this approach should become one of the many alternatives and orientation for education practitioners, in order to improve students' active speaking ability,

(3) The communicative-based instructional speaking skill model was effective for teachers to boost students' functional speaking ability. The implication is that this approach should be acknowledged as an educational tool, in order to increase students' active speaking ability.

28 Suwarsih Madya, "Metodologi Pengajaran Bahasa: Dari Era Prametode Sampai Era Pascametode," Language Teaching Methodology from Premethod Era to Postmethod Era). Yogyakarta: UNY Press, 2013.

${ }^{29}$ Supharatypthin, "Developing Students' Ability In Listening And Speaking English Using The Communicative Approach Of Teaching." 


\section{CONCLUSION}

Based on the results and discussions, some conclusions were drafted as follow, (1) The experts'/practitioners' responses towards the communicative-based instructional speaking skill model were valid, as these were supported by the construct and content validation scores of $94 \& 130$, respectively.

(2) There was a significant difference in students' active speaking abilities, after and before implementing the instructional model. This was observed from the statistical analysis result, which involved the use of t-test at $\alpha=0.05$, where the value produced was 0.000. The indicated that the significance value was lower than 0.05. Also, the average score of the students' speaking ability before and after the knowledge of communicativebased instructional speaking skill model, were $66.22 \& 78.77$, respectively.

(3) The implementation of the instructional model was also effective in increasing the students' active speaking ability.

(4) The performance of the instructional model at an average score of 61 , was categorized as high, or easily applied.

Moreover, the development of communicative-based instructional speaking skill model was also observed to have fulfilled the criteria of product, as it was effective in increasing students' active verbal ability. Therefore, some suggestion were proposed, such as,

(1) Communicative-based instructional speaking skill model should be used by teachers in facilitating innovative instruction, as an effort to increase students' active verbal ability. (2) Schools are expected to encourage teachers into prioritizing the application of communicative-based innovative instruction.

(3) The government should aid the training of teachers into creating instructions, by utilizing daily life environmental situations as the source of language teaching and learning processes.

(4) Communicative-based instructional model should also be used by subsequent researchers. 


\section{REFERENCES}

Ahmad Rofi'uddin \& Darmiyati Zuchdi. Pendidikan Bahasa dan Sastra Indonesia di Kelas Tinggi. Malang: Universitas Negeri Malang, 2001.

Ali Mustad. Communicative Competence-Based Language Teaching: An English Course Design for Primary Teacher Education. Cet. II. Yogyakarta: UNY Press, 2013.

Anggun Kirana Putri, Kartika Chrysti S. \& Suripto. "Pendekatan Komunikatif dalam Peningkatan Keterampilan Berbicara Bahasa Inggris Dilihat dari Motivasi Belajar Siswa", Jurnal FKIP-UNS, 2012.

Asna Yuliati. "Penerapan Pendekatan Komunikatif dalam Pembelajaran Bahasa Indonesia". Jurnal Wahana Pedagogika. Lamongan: Universitas Islam Darul Ulum, Vol. 2, No. 1, Juni 2016.

Atmazaki, Atmazaki. "Implementasi Kurikulum 2013 Mata Pelajaran Bahasa Indonesia: Pola Pikir, Pendekatan Ilmiah, Teks (Genre), Dan Penilaian Otentik." International Conference on Languages and Arts 0, no. 0 (October 31, 2013): 1522. http://ejournal.unp.ac.id/index.php/isla/article/view/3962.

Bashir, Marriam, Muhammad Azeem, and Ashiq Hussain Dogar. "Factor Effecting Students' English Speaking Skills." British Journal of Arts and Social Sciences 2, no. 1 (2011). http://widyawatipalupi.blogs.uny.ac.id/wpcontent/uploads/sites/15732/2018/04/Factors-effecting-students-speakingskill.pdf.

Borg, W.R., \& Gall, M.D. Educational Research an Introduction (7 ${ }^{\text {th }}$ ed.). New York: Longman, Inc., 2003.

Buckley, B. The Children Communication Skill-from Birth to Five Years Chapter I Early Language Development. Retrieved from http://www.early-education.org. uk., (2013).

Burhan Nurgiyantoro, Gunawan, \& Marzuki. Statistik Terapan: untuk Penelitian IlmuIlmu Sosial. Cet. Ke-3. Yogyakarta: UGM Press, 2004.

Burhan Nurgiyantoro. Penilaian Pembelajaran Bahasa Berbasis Kompetensi. Edisi Ke1. Cet. Ke-1. Yogyakarta: BPFE Yogyakarta, 2010.

Celce-Murcia, Marianne, and And Others. "Communicative Competence: A Pedagogically Motivated Model with Content Specifications." Issues in Applied Linguistics 6, no. 2 (1995): 5-35. https://eric.ed.gov/?id=EJ542906.

Feti Ramadani. "Pengaruh Penerapan Pendekatan Komunikatif terhadap Keterampilan Berbicara Siswa Kelas IV pada Pembelajaran Bahasa Inggris di MI Negeri 1 Teladan Palembang". Palembang: FITK UIN Raden Fatah, 2017.

Iskandarwassid \& Dadang Sunendar. Strategi Pembelajaran Bahasa. Bandung: Rosda, 2008.

Jack C. Richard. Communicative Language Teaching Today. Cambridge: Cambridge University Press, 2006.

Kementerian Pendidikan dan Kebudayaan. Panduan Penguatan Proses Pembelajaran Sekolah Menengah Pertama. Jakarta: Kemendikbud, 2013. 
Kurdi, Muqarramah Sulaiman, Mardiah Mardiah, Musyarrafah Sulaiman Kurdi, Muhammad Iqbal Ghazali Usman, and Taslimurrahman Taslimurrahman Taslimurrahman. "Speaking Activities In Madrasah Ibtidaiyah: A Meta Narrative About Character Building And Multiculturalism Point Of View." Al-Bidayah : Jurnal Pendidikan Dasar Islam 12, no. 1 (June 30, 2020): 55-82. https://doi.org/10.14421/al-bidayah.v12i1.534.

Lee, Moon Woo. "Will Communicative Language Teaching Work? Teachers' Perceptions Toward The New Educational Reform In South Korea." Indonesian Journal of Applied Linguistics 3, no. 2 (January 2, 2014): 1-17. https://doi.org/10.17509/ijal.v3i2.265.

Mohammad Nurul Islam. "Communicative Approach: Some Misapprehensions". International Journal of Academic Research in Business and Social Sciences January 2012, Vol. 2, No. 1 ISSN: 2222-6990.

Murcia, M.C. Rethinking the Role of Communicative Competence in Language Teaching. Journal of Intercultural Language Use and Language Learning, 41-57, 2007.

Piirto, J.. Creative for 21 st Century Skill. Retrieved from http://ww.sensepublisher.com., (2011).

Rabawati, Kentarsih, M. Sutama, and M. Gosong. "Penerapan Pendekatan Komunikatif Dalam Pembelajaran Bahasa Indonesia Siswa Kelas XI Smk Negeri 1 Denpasar." Jurnal Pendidikan Dan Pembelajaran Bahasa Indonesia 2, no. 0 (May 22, 2013). https://ejournal-pasca.undiksha.ac.id/index.php/jurnal_bahasa/article/view/581.

Ratna, Ellya. "Pengembangan Materi Ajar Bahasa Indonesia Berdasarkan Pendekatan Komunikatif". Jurnal Bahasa dan Seni. Padang: FBSS UNP Press. 7, 2, 1411 3732 (2006).

Richard Arends.Classroom Instructional Management. New York: The Mc Graw-Hill Company, 1997.

Rugare Mareva \&Shumirai Nyota. "Structural or Communicative Approach: a Case Study of English Language Teaching in Masvingo Urban and Peri-Urban Secondary Schools". Internal Journal of English and Literature Vol. 3(5), pp. 103111 (2012).

Saldaria, Elnida, Vina Anggia Nastitie Ariawan, and Isah Cahyani. "Speaking Skill Of Elementary Students Reviewed By Gender." Jurnal Prima Edukasia 7, no. 1 (January 28, 2019): 20-27. https://doi.org/10.21831/jpe.v7i1.20363.

Sukarno, Sukarno. "Politeness Strategies, Linguistic Markers And Social Contexts In Delivering Requests In Javanese." Indonesian Journal of Applied Linguistics 7, no. 3 (January 31, 2018): 659-67. https://doi.org/10.17509/ijal.v7i3.9816.

Supharatypthin, Dissaya. "Developing Students' Ability In Listening And Speaking English Using The Communicative Approach Of Teaching." International Journal of Arts \& Sciences 7, no. 3 (2014): 141-49. https://search.proquest.com/openview/826a03fb9d977240569d829d126fe56f/1? pq-origsite $=$ gscholar $\& \mathrm{cbl}=626342$. 
Suwarsih Madya. Metodologi Pengajaran Bahasa: dari Era Prametode sampai Era Pascametode. Ed. 1. Cet. Ke-1.. Yogyakarta: UNY Press, 2013.

Yunus Abidin. Pembelajaran Bahasa Berbasis Pendidikan Karakter. Cet. Ke-3. Bandung: PT Refika Aditama, 2015. 
This page is intentionally left blank 